\title{
Analysis of Speaking Ability of Students of English Education Study Program of UMN Al Washliyah through Vlog on Instructional Planning and Media Course
}

\author{
Yugi Diraga Prawiyata ${ }^{1}$, Ulian Barus ${ }^{2}$ \\ ${ }^{1}$ English Education Study Program, ${ }^{2}$ Civic Education Study Program, \\ ${ }^{1,2}$ Faculty of Teacher Training and Education, Universitas Muslim Nusantara Al-Washliyah \\ Corresponding Author: Yugi Diraga Prawiyata
}

\begin{abstract}
The objective of this research was to determine how students' speaking skill of UMN Al Washliyah English Education Study Program through vlogs on Instructional Planning and Media course was. This research used a descriptive qualitative research design, in which the researcher described and analysed speaking skill. The population in the research was 10 students of UMN Al Washliyah English Education Study Program in semester III-V in Academic Year 2020/2021, totalling 10 people. Based on the study results, it can be concluded that the students' speaking skill was between the levels "Above Average" and "Excellent." In other phrases, it may be concluded that vlog media may be an interesting alternative media that may be used to improve college students' speaking skill.
\end{abstract}

Keywords: speaking skill, media, vlog

\section{INTRODUCTION}

Language skills include listening, speaking, reading, and writing skills. Therefore, it can be understood that for language learning, more attention is paid to language performance, not only to language understanding, that is, using language expressions in a certain context based on the communicative function of language (Abidin et al., 2015).

Tarigan (1990:3) says that speaking is a language skill that develops in a life preceded by listening skills and at that time the ability to speak began to be learned since entering the school world, the child is faced with two ranges namely, the range of language skills and the range of language attitudes. At one end of the range you want to express your thoughts, and at the other end of the range you are afraid to speak. Therefore, in this case, the teacher has the responsibility to strengthen the child's language beliefs, because learning oral skills requires confidence in speech.

It is quite difficult to increase the confidence of students when speaking, so it takes a lot of time and patience of the teacher to guide the students. The teacher should create an atmosphere in which students can practice directly in spoken English. The teacher must also be able to encourage students to tell, describe, report, explain, review, design, and many other activities orally.

Tarigan (1990:15) then says that speaking is the ability to speak articulated sounds or words to express, say, and convey ideas and feelings. Speaking is the act of using language orally. As a social person, human beings always use language to communicate with others in social life. Therefore, it can be concluded that speaking is part of language skills, so students are required and trained to have good speaking skills. There are many ways to improve your 
presentation skills, one of which is through video blogging.

Speaking is the most important aspect when learning a second language or foreign language. This success can be measured by the ability of students or learners to engage in dialogue and verbal interaction with language (Nunan, 2000: 39). Speaking is very important in our lives, because without speaking we cannot know what people are saying, and speaking is also a way for us to interact with others.

Based on the expert explanation of speaking skills, the researcher can elaborate the components of speech in each theory as Hormailis (2003:6) states that there are four aspects below that have a major influence in speaking skills, namely:

\section{a. Vocabulary}

Vocabulary is one of the extreme aspects of oral activity support. It has to do with correct and adequate words.

\section{b. Grammar}

If you can understand the grammar, you will communicate fluently when speaking. Therefore, speakers must know the grammar they use when speaking. In other words, grammar is the rule by which we collect meaningful words and language parts to convey understandable information.

\section{c. Fluency}

Speech is the activity of verbally reproducing words. This means that there is a brainstorming process between the speaker and the listener. Therefore, it is important to have another component of speaking skills, fluency. Fluency means being able to use language spontaneously and safely without pause or hesitation.

\section{d. Pronunciation}

Pronunciation is producing speech for communication, which is very important in communication.

Later, Khan (2013) presented a rubric designed to help teachers assess oral presentations prepared by students at the Intermediate/Advanced level. The rubric contains the following categories to be assessed: originality, structure, language use (grammar and syntax), vocabulary, pronunciation and overall presentation.

Khan (2013) also stated that there are four ratings in each category in the rubric designed to help teachers assess prepared oral presentations, namely Rating: 1=Below Average, 2=Satisfactory 3=Above Average, 4= Excellent.

Based on the explanation of the theory above, the researcher can conclude that the components of speech suitable for advanced level, namely in students include originality, structure, grammar, vocabulary, pronunciation, and understanding. This means that when speaking, the speaker must pay attention to those components in order to become a good speaker.

The development of digital media technology has released everyone's creative potential to create interesting content. Vlog is a digital medium that contains personal monologues about opinions or personal experiences (Sugiono \&Irwansyah, 2019).

YouTube is one of the biggest resources people use to upload, share, and watch videos, but video blogging can also be done on Facebook, personal websites, Twitter, or many other channels. People can create a video using a webcam, phone, or video camera, and then upload the video to the network to share it with specific people or the world. The Vlog is usually updated regularly, but the video can be edited, changed or uploaded at any time (Brokamp et al., 2020).

The existence of YouTube as a social network has led to changes in the form of self-presentation. Lestari (2019) pointed out that self-presentation is closely related to the construction of identity. It can be said that a person presents himself, because he can interact with others, but the construction of identity is not only about oneself, but also about others. From that statement it can be concluded that every vlogger has expectations about the expectations of other people. This motivates you to do something to create a positive 
image while pouring in information to create the identity you want.

Vlogs can also be used for personal expression and reflection. As a result, video blogs are incorporated into portfolios and electronic presentations. Using video blogs for digital storytelling can be a way to encourage students to actively participate in electronic portfolio projects (Brokamp et al., 2005).

From some of the above statements, it can be said that students will actively speak according to their interest shown through the video blog, so that they will be motivated to continue creating.

\section{METHODS}

The research method used in this study was descriptive research. This study used a variable, so the appropriate method was to use a qualitative method. Bogdan and Biklen (1982) said, "Qualitative research are the direct source of data, and the researchers are the key instruments." Then, descriptive research was chosen because it presented data about facts in the field in a systematic, objective and accurate way. Descriptive research aims to describe, explain, explain, and answer the research questions in more detail by studying as many individuals, groups or events as possible.

This research was conducted at Univeristas Muslim Nusantara AlWashliyah, in the English Education Study Program, Faculty of Teacher Training and Education in the odd semester in academic year 2020-2021.

Data from this study was the fluency in speaking English as well as content presented by the semester $5 \mathrm{~V}$ students of Univeristas Muslim Nusantara AlWashliyah, in the English Education Study Program in the form of vlogs shared on YouTube social media. While as a data source was the semester $5 \mathrm{~V}$ students of English Education Study Program who were taking Instructional Planning and Media course as many as 10 people.

In this study the instrument for obtaining data from students' speaking skill was an oral test using Vlogs uploaded on a YouTube channel as a medium for analysing and validating data. In this test the researcher asked students to talk about a specific topic given by the researcher.

Then, the researcher analysed by identifying and classifying their content as Khan (2013) mentioned in the form of oral presentation rubrics as containing the following categories that will be assessed in terms of originality, structure, language use, vocabulary, pronunciation, and delivery of overall presentation.

\section{RESULTS AND DISCUSSION}

The data in this study was in the form of students' speech in speaking English which was documented in the vlog media where there are several categories of content in it. Then as mentioned in the previous chapter the researcher analyzed about their content as Khan (2013) mentioned in the form of an oral presentation rubric consisting of based on originality, structure, language use (grammar and syntax), vocabulary, pronunciation and overall presentation.

Tabel 1 The Students' Speaking Skill in Originality
\begin{tabular}{|l|l|l|l|l|}
\hline Rating & Converted Score & Interval & Number of Students & Percentage \\
\hline Excellent & 4 & $96-100$ & 10 & $100 \%$ \\
\hline Above Average & 3 & $81-85$ & 0 & $0 \%$ \\
\hline Satisfactory & 2 & $66-70$ & 0 & $0 \%$ \\
\hline Below Average & 1 & $0-55$ & 0 & $0 \%$ \\
\hline
\end{tabular}

Table 1 shows that all students $(100 \%)$ maintained audience interest in a smart and innovative way and achieved presentation objectives by maintaining the originality of the content of the vlog.
Table 2 shows that students' speaking skill on the Structure aspect vary from a score of two to four. As many as two students $(20 \%)$ was at the "Excellent" level where the introduction and actual 
presentation are very well organized and easy to understand. Then the "Above Average" level dominates the most $(80 \%)$ where students kept the audience's attention throughout the vlog and the presentation objectives were achieved.

Tabel 2 The Students' Speaking Skill in Structure
\begin{tabular}{|l|l|l|l|l|}
\hline Rating & Converted Score & Interval & Number of Students & Percentage \\
\hline Excellent & 4 & $96-100$ & 2 & $20 \%$ \\
\hline Above Average & 3 & $81-85$ & 8 & $80 \%$ \\
\hline Satisfactory & 2 & $66-70$ & 0 & $10 \%$ \\
\hline Below Average & 1 & $0-55$ & 0 & $0 \%$ \\
\hline
\end{tabular}

Tabel 3. The Students' Speaking Skill in Language Usage (Grammar and Syntax)

\begin{tabular}{|l|l|l|l|l|}
\hline Rating & Converted Score & Interval & Number of Students & Percentage \\
\hline Excellent & 4 & $96-100$ & 2 & $20 \%$ \\
\hline Above Average & 3 & $81-85$ & 7 & $70 \%$ \\
\hline Satisfactory & 2 & $66-70$ & 1 & $10 \%$ \\
\hline Below Average & 1 & $0-55$ & 0 & $0 \%$ \\
\hline
\end{tabular}

Table 3 shows that students' speaking skills in aspects of Structure (Grammar and Syntax) differ from two to four scores. There were two students $(20 \%)$ which got a score of 4 where students used the best sentence structure/syntax that supported the topic.

Slang was hardly ever used. Then, seven students $(70 \%)$ got a score of 3 where they used the correct sentence structure/syntax and fit in support of the topic. No slang was used. Lastly, only one student $(10 \%)$ who got a score of 2 where the student used the correct sentence structure/syntax which mostly fit the topic. However, some slang terms were still used.

Tabel 4. The Students' Speaking Skill in Vocabulary

\begin{tabular}{|l|l|l|l|l|}
\hline Rating & Converted Score & Interval & Number of Students & Percentage \\
\hline Excellent & 4 & $96-100$ & 8 & $80 \%$ \\
\hline Above Average & 3 & $81-85$ & 2 & $20 \%$ \\
\hline Satisfactory & 2 & $66-70$ & 0 & $10 \%$ \\
\hline Below Average & 1 & $0-55$ & 0 & $0 \%$ \\
\hline
\end{tabular}

Table 4 shows students' speaking skill on aspects of Vocabulary seen eight students $(80 \%)$ are at the "Excellent" level where students used the best vocabulary for the audience, and defined words that may still be new to most audiences. Furthermore, two students are at the "Above average" level $(20 \%)$ which they used vocabulary that was appropriate for the audience. However, it contained one to two words that may still be new to most audiences, but did not define them.

Tabel 5. The Students' Speaking Skill in Pronunciation
\begin{tabular}{|l|l|l|l|l|}
\hline Rating & Converted Score & Interval & Number of Students & Percentage \\
\hline Excellent & 4 & $96-100$ & 2 & $20 \%$ \\
\hline Above Average & 3 & $81-85$ & 3 & $30 \%$ \\
\hline Satisfactory & 2 & $66-70$ & 5 & $50 \%$ \\
\hline Below Average & 1 & $0-55$ & 0 & $0 \%$ \\
\hline
\end{tabular}

Table 5 shows students' speaking skills in the Pronunciation aspect, which is seen by five students $(60 \%)$ are at the "Satisfactory" level where they spoke clearly and almost all the time (100-95\%) and mispronounced two to five words in the presentation. Then, three students (30\%) are at the "Above Average" level where they spoke clearly all the time (100-95\%), but mispronounced one word. Lastly, as many as two students $(20 \%)$ are at the "Excellent" level where they spoke clearly all the time (100-95\%), and did not mispronounce directly even a word. 
Yugi Diraga Prawiyata et.al. Analysis of speaking ability of students of English education study program of UMN Al Washliyah through vlog on instructional planning and media course.

Tabel 6. The Students' Speaking Skill in Delivery
\begin{tabular}{|l|l|l|l|l|}
\hline Rating & Converted Score & Interval & Number of Students & Percentage \\
\hline Excellent & 4 & $96-100$ & 2 & $20 \%$ \\
\hline Above Average & 3 & $81-85$ & 2 & $20 \%$ \\
\hline Satisfactory & 2 & $66-70$ & 5 & $50 \%$ \\
\hline Below Average & 1 & $0-55$ & 1 & $10 \%$ \\
\hline
\end{tabular}

Lastly, table 6 shows students' speaking skill in the delivery aspect, it appears that the level of "Satisfactory" is dominated by five students $(50 \%)$ which they were rather prepared for; presentation was done but with a strong dependence on notes and doubts, some eye contact and volume were also influential, good tone and tempo, but the right gestures supported the presentation.

Then, as many as two students $(20 \%)$ were at the "Above Average" level where they prepared well and conveyed ideas through focused eye contact, the volume of sound, tone and tempo were also precise, and gestures supported the entire presentation. Then, as many as two students were at the "Excellent" level which they prepared very well and conveyed ideas clearly and concisely, without relying too much on notes, and the volume, tempo and gestures contributed maximally on the presentation.

Meanwhile, there was a student $(10 \%)$ at the "Below Average" level where the presenter was clearly not ready to perform in front of the audience. It was characterized by lack of eye contact, volume, tone and poor tempo. Inappropriate gestures interfered with the presentation.

\section{CONCLUSION AND SUGGESTION Conclusion}

From the results and discussion of research, it can be concluded that the dominance of every aspect in their vlog content is described as follows:

1. Ten students maintain the "Originality" aspect at the "Excellent" level. Eight students are in the "Structure" aspect at the "Above Average" level. Seven students are in the "Language Usages" aspect at the "Above Average" level. Eight students maintain the "Vocabulary" aspect at the "Excellent" level. Five students are in the "Pronunciation" aspect at the "Satisfactory" level. Five students are in the "Delivery" aspect at the "Satisfactory" level.

2. Seven students filled out the cooking vlog, two students filled out the DIY/tutorial vlog, and one student filled out the reviewing vlog.

3. Overall, students' speaking skill are between the "Above Average" and "Excellent" or "Excellent" levels.

\section{Suggestion}

After the research and data processing are complete, there are some suggestions, as described by the researcher, as follows:

1. Teachers are advised to choose alternative learning media that is attractive and varied so that students can be more active and creative in the learning process.

2. Teachers should always use various media in every learning process, to improve students' language skills.

3. Students are expected to practice their speaking skills inside and outside the classroom to gain better speaking skills, especially with the support of various learning media, such as using vlog.

\section{Acknowledgement: None}

\section{Conflict of Interest: None}

\section{Source of Funding: None}

\section{REFERENCES}

1. Abidin dkk. (2015). Peningkatan Kemampuan Berbicara Pembelajaran Bahasa Indonesia dengan Teknik Bercerita (Story Telling) pada Sekolah Dasar. Jurnal Pendidikan dan Pembelajaran Khatulistiwa, 4(11), 3-13 
2. Bogdan, R. C., \& Biklen, S. K. (1992). Qualitative Research for Education: An Introduction to Theory and Methods. Boston: Allyn and Bacon.

3. Brokamp dkk. (2020). What is Vlog? Diakses pada 22 Oktober 2020 di https://socialmediaandtheclassroom415.wee bly.com/vlogging.html/

4. Hormailis. (2003). The Use of Group Work Technique for the Improvement of Speaking Ability the Second Year Student on MAN 2 Pekanbaru. Pekanbaru: Unpublished Thesis

5. Khan, Roselline. (2013). Oral Presentation Rubric. Diakses pada 12 Januari 2021 di https://en.islcollective.com/ english- eslworksheets/material-type/pronunciationactivities/oral-presentation-rubric/48396

6. Kuncoro, A.M, dkk. (2018). Vlogger Sebagai Saluran Menuju Generasi Milenial Produktif Indonesia. UNEJ e-Proceeding, 3(3),193-199

7. KaiaMedia. (2016). Pengertian Vlog. Diakses pada 22 Oktober 2020 di http://www.kaiamedia.com/pengertian-vlog/

8. Lestari, A.D. (2019). Video Blogging (Vlogging) sebagai Bentuk Presentasi Diri. Jurnal Signal. 7(1), 39-45

9. Lincoln, Y.S \& Guba E.G. (1985). Naturalistic Inquiry. Beverly Hills California. Sage Publication, Inc.
10. Nunan, D. (2000). Language Teaching Methodology. Malaysia city: Pearson Education Ltd.

11. Samsung. (2018). Apa Itu Vlog dan Bagaimana Membuatnya. Diakses pada 22 Oktober 2020 di https://www.samsung.com/id/discover/mobi lephone/apa-itu-vlog-dan-bagaimanamembuatnya/

12. Sugiono \& Irwansyah. (2019). Vlog sebagai Media Storytelling Digital bagi Tokoh Publik Pemerintahan. Jurnal Studi Komunikasi dan Media. 23(2) 2019

13. Tarigan, H.G. (1990). Berbicara Sebagai Suatu Keterampilan Berbahasa. Bandung: Angkasa

14. Wikipedia. Blog Video. Diakses pada 22 Oktober 2020 di https://id.wikipedia.org/wiki/Blog_video/

How to cite this article: Prawiyata YD, Barus U. Analysis of speaking ability of students of English education study program of UMN Al Washliyah through vlog on instructional planning and media course. International Journal of Research and Review. 2021; 8(8): 522-527. DOI: https://doi.org/10.52403/ijrr. 20210871 